\title{
Effect Of Foreign Aid On Educational Development In Nigeria
}

\author{
Tijjani Mohammed Mukaddas
}

Researcher, Department of Science and Environmental Education, University of Abuja, Mini campus Gwagwalada, Nigeria, tjmuqaddas@gmail.com

Received:15 Nov, 2019 Revised: 11 Dec, 2019 Accepted: 04 Jan, 2020 Published: 28 Jan, 2020

How to cite this paper: Mukaddas, T.M. (2019). Effect of foreign aid on educational development in Nigeria. Quest Journal of Management and Social Sciences, 1(2), 202-209.

Copyright (C) 2019 by authors and Quest Journal of Management and Social Sciences

This work is licensed under a Creative Commons Attribution-NonCommercial-NoDerivatives 4.0 International License.

https://creativecommons.org/licenses/by-nc-nd/4.0/

\begin{abstract}
Background: Education is necessary for the economic growth and political stability of any nation. Due to the lack of resources, Nigeria does not pay necessary attention to education. In recent years Nigeria has reduced the budgetary allocation for education sector. Like in other sectors, Nigeria relies heavily on foreign aids for the development of the educational institutions.
\end{abstract}

Objective: The study aims at assessing the effect of foreign aid on educational development in Nigeria and to give policy recommendations based upon the conclusion drawn from this study.

Methods: The study, conducted in Nigeria, employed descriptive survey research design and data were collected using key stakeholders questionnaire as research tools. Data were analyzed using descriptive and inferential statistics for research questions and t-test statistics to answer the research hypothesis.

Results: Findings from this study revealed that foreign aid has positively affected Nigeria education in terms of infrastructure, SDGs, UBE, science and technology, human resources and ICT.

Conclusions: The foreign aid to education has a positive impact on Nigerian educational development.

Implications: The result generated from this study can be considered by education policy makers of Nigeria and concerned authorities.

Recommendations: The study recommended that donor countries/agencies should allow Nigeria to design and formulate its own policies according to her culture and traditions. It is also recommended that foreign aid intervention should be carried out more in rural communities especially in the area of critical infrastructures in $\mathrm{Ni}$ gerian schools.

Keywords: Foreign, aid, education, development, Nigeria

Originality: This is original paper and not sent anywhere else for publication.

Paper Type: Research paper

JEL Classification: I21, I22, I25 


\section{Introduction}

Foreign aids in Nigeria have been in existence since the creation of national states and republics of Nigeria. The developed or rich countries have always assisted the developing or poor countries to achieve similar achievements to provide livelihoods for their citizens. The history of foreign aid can be traced back to the 1940 o following the destruction caused during the Second World War. Some of the post Second World War challenges were the collapse of the international economic systems characterized by shortage of capitals required for infrastructure reconstruction. In the past four decades, however, there has been an increase in foreign aids to developing and least developed countries in the area of education and health. The concept of foreign assistance is a voluntary action dependent on need of the recipient countries from a donating country, governments, private organizations, individuals for the economic growth of recipient countries (Ouattara, 2006). Nigeria has benefitted from various schemes of foreign aids, however, she is still struggling for the self-sufficeincy in all aspects of development (Oshewolo, 2011). On the other hand. some countries that were recipients of aids in the past developed to the level that now that they have become aid donors (South Korea, and China etcetera).

There are diverse scholarly opinions on whether foreign aid on education has contributed to development in Nigeria or not. Fasanya and Onakoya (2012) posited that, although Nigeria has continued to benefit from all sorts of foreign assistance and, in fact, still receives as much foreign aids as possible, yet socio-economic development has remained gloomy. Abdulhamid (2008) stated that the total net aid flows from all donors that Nigeria received was US\$ 152 million in 1999; in 2000, aid flows increased slightly to $\$ 185$ million and by 2004 , it reached $\$ 573$ million. Aid flows to Nigeria in the wake of its return to civilian rule sharply increased, this was manifested in the volume of foreign aid influx into the country covering the period 1999-2007. According to Alabi (2012), Nigeria recorded the following volume of aid influx: $\$ 6.799$ billion in 2005; it rose to $\$ 11.781$ billion in 2006 ; but later fell to $\$ 1.385$ billion in 2007; $\$ 1.401$ billion and it was constant at $\$ 1.638$ billion in 2008 and 2009.

Nigeria has recently been receiving foreign aids for infrastructural development, development of human resource for learning and teacher development, ICT in teaching and learning, science and technology, and Education for All, etc. The Government of Nigeria has been working in active collaboration with International Development Partners such as the British council, United Nations International Children Education Fund (UNICEF), Department for International Development (DFID), United Nation Educational, Scientific and Cultural Organization (UNESCO), United State Agency for International Development (USAID), Japan International Cooperation Agency (JICA), Korea International Cooperation Agency (KOICA), Chinese Government Cooperation (CGC), World Bank as well as Civil Societies and Non-governmental Organizations (NGOs) to achieve the Education for All and Universal Basic Education goals and Sustainable Development Goals (SDGs, etc.

Despite the efforts in improving the quality of education by Nigeria government and its donors, the performance of educational institutes is yet below the expectations of stakeholders such as students, parents, teachers, governments, general public and international organizations. Some scholars believed that Nigeria's development indicators have not im- 
proved but unfortunately getting deterioted in spite of continuous foreign aids for decades. At present, nearly 10 million school age children are not attending schools and more than two million Nigerian children study abroad. This is suggestive of the poor educational settings and improper implementation of foreign intervention. This study is carried out to investigate the effect of foreign aids on educational development in Nigeria. This study aims at providing empirical evidence on this issue. Besides, this study also aims at determining the effectiveness of foreign aid in educational development in Nigeria. The study specifically examines national and foreign stakeholders' perceptions on the successes of foreign aid intervention to educational development in Nigeria, and compares national and foreign stakeholders' negative and positive views on the effectiveness of foreign aids to educational development in Nigeria.

In the remaining parts, Section 2 critically examines the available and relevant literature; Section 3 describes the materials and method used; Section 4 presents results and discusses then and, finally, Section 5 draws the concluding remarks and offers recommendations.

\section{Review of Literature}

\section{Foreign Aids in African Countries}

Rostow (1990) argues that foreign aid is the imposition of the developed countries on the less developed countries as a prerequisite for economic development. On the contrary, Hayter, (1971) views foreign aid as a form of modern imperialism and may not lead to the anticipated economic benefits initiatives. This status quo has led to the frequent inflow of capital from developed countries to developing countries in an attempt to reduce the gap while overcoming their problems. According to Andrews (2009), in spite of foreign aids for several decades in African countries, there has been no significant changes to their destinies. Most of these countries continue to exhibit slow development rates.

Although there has been extensive flow of foreign aids to developing nations and extensive empirical work for decades on the aid-growth link, the aid effectiveness literature remains controversial. An important objective of foreign aid to less developed countries is to enhance their economic development and welfare, this is more often measured by the impact that it has on economic growth. Despite decades of transfer of foreign capitals to the developing countries, there is evidence from numerous studies that seeks to unmask the relationship between aid and economic development, that there has been less evidence of achieving these objectives (Durbarryet al., (1998).

Girmaet al. (2005) study on 25 sub-Saharan African countries, from 1970 to 1997 showed that the aid appears to be ineffective. Tarp \& Director (2009) agree that aid is still an important tool for enhancing the growth outlook of poor countries. This includes the access to such services as health and education and food security which are significant determinants of the human capital that participates in the economic growth of the country. Gani \& Clemes (2003) study found that there was an effect of aid on human development, which was found in health and education and also showed a significant correlation in terms of human development among the lower-middle countries. 


\section{Foreign Aid on Education to Nigeria}

Dreher et al. (2015) pointed out that many of the developing countries receiving aids, poverty still looms large, and underdevelopment persists while concluding that there is no robust evidence that aid affects growth. On the other hand, Alemu and Lee (2015) in their work on the comparative analysis of the impact of foreign aid on Middle and Low-Income African countries concluded that aid has a significant positive impact on low-income countries arguing that criticisms of foreign aid is flawed. Galiani et al. (2014) also pointed out that foreign aid has a sizable positive effect on economic growth. Adeyeye (2013) pointed out that theft and misappropriation of development aids are thriving, too. These issues have not been taken seriously by the government to bring the concerned people under legal system through appropriate prosecution and such practices are behind the under-developed state of Nigeria. Oshewolo (2011) further stated, "aids may fail to help the vulnerable, as aid money can often be embezzled".

Adewole (2014) revealed that foreign aid in 2010 was spent mostly on administration, which received $26.9 \%$ of total aid. In the same year, $5.4 \%$ of aid was allocated to agriculture; 9.4\% to energy and mining; $1.9 \%$ to industry and trade; and $6.8 \%$ to transportation. Mbah and Amassoma (2014) also adduced that the negative impacts of foreign aid stems from the result of channeling most aid funds to unproductive use thereby limiting the great potentials of foreign aid in promoting growth.

\section{Research Methods}

The study employed the descriptive survey research design. The choice of this design was because the researcher goes out to gather information that was already on ground which is used to describe the behavior of a research population. Fifty national education stakeholders and fifty foreign diplomats were sampled for the purpose of this study using simple random sampling procedure. This population includes those of public and private education institutions, embassies and high commissions of different donor countries in Nigeria.

Two versions of a 10 item in-depth interview questionnaires entitled 'Effect of Foreign Aid to Educational Development in Nigeria (EFAEDN)" were designed along a 4-point Likert scale by the researcher. The first verion of questionnaire was for national education stakeholders while the second for foreign diplomats in Nigeria. The instrument comprises both negative and positive effects of foreign aid to educational development that may be important in the study. The items are similar except that the wordings have to be structured for the two groups differently. The instrument had very good psychometric properties. The reliability index of the instrument using the split - half method was 0.76 due corrections with spearman Brown's prophesy formula.

Analysis of data was carried out using descriptive statistic such as frequency count, mean scores in the case of research questions. The hypothesis was tested at 0.05 level of significance using t-test with help of SPSS. On the basis of questions raised above, one null hypothesis was tested. It is hypothesized that; there is no significant difference between national stakeholders and foreign donors' perceptions on the effect of foreign aid to educational development in Nigeria. 


\section{Data Analysis and Result}

Research question one: What is the national stakeholders' perception on the effect of foreign aid to educational development in Nigeria?

Table 1: Nigeria education stakeholders' perceptions on effect of foreign aids on educational development in Nigeria.

\begin{tabular}{|c|c|c|c|c|c|c|}
\hline \multirow{2}{*}{$S / \mathbb{N}$} & \multirow{2}{*}{ ITEM } & \multicolumn{5}{|c|}{ RESPONSES } \\
\hline & & SA & A & D & $\mathrm{SD}$ & $x$ \\
\hline 1 & $\begin{array}{l}\text { Do you feel foreign aid has helped Nigeria to achieve SDGs } 4 \\
\text { (Ensure inclusive and equitable quality education and promote } \\
\text { lifelong learning opportunities for all)? }\end{array}$ & 14 & 16 & 12 & 8 & 2.72 \\
\hline 2 & Do you feel foreign aid has improved essential infrastructure? & 10 & 4 & 26 & 10 & 2.28 \\
\hline 3 & $\begin{array}{l}\text { Has the foreign aid helped Nigeria to achieve Universal Basic } \\
\text { Education goals? }\end{array}$ & 12 & 22 & 14 & 2 & 2.88 \\
\hline 4 & $\begin{array}{l}\text { Do you feel foreign aid has improved Information and } \\
\text { communication techology in Nigeria education institutions? }\end{array}$ & 9 & 5 & 19 & 17 & 2.66 \\
\hline 5 & $\begin{array}{l}\text { Do you feel the foreign aid has led to improvement in the outcome } \\
\text { of education at primary, junior and secondary school levels? }\end{array}$ & 11 & 7 & 15 & 17 & 2.24 \\
\hline 6 & $\begin{array}{l}\text { Do you feel foreign aid has negative effects on educational } \\
\text { development in Nigeria? }\end{array}$ & 6 & 16 & 12 & 17 & 2.26 \\
\hline 7 & $\begin{array}{l}\text { Do you feel foreign aid has improved science and technology } \\
\text { through research innovations in Nigeria universities? }\end{array}$ & 14 & 9 & 16 & 11 & 2.52 \\
\hline 8 & $\begin{array}{l}\text { Do you think foreign aid has led to improvement of student } \\
\text { outcome at senior secondary school level }\end{array}$ & 18 & 12 & 10 & 10 & 2.76 \\
\hline 9 & $\begin{array}{l}\text { Do you feel foreign aid has improved school enrollment of girl } \\
\text { child education in Nigeria? }\end{array}$ & 14 & 22 & 12 & 2 & 2.96 \\
\hline 10 & $\begin{array}{l}\text { Do you feel Nigeria rely on foreign aid intervention in the area of } \\
\text { education development? }\end{array}$ & 22 & 24 & 3 & 1 & 3.34 \\
\hline & Overall Mean & & & & & 2.66 \\
\hline
\end{tabular}

Table 1 shows an average mean score of 2.66 for education stakeholders in Nigeria. This implies that foreign aid on education has positive impact on the educational development in Nigeria. It also indicates that success rates have recorded in the areas of infrastructure, ICT, UBE, SDGs as well as improvement in science and technology, teacher education and student academic achievement.

Research question Two: What is the foreign stakeholders/donors' perceptions on the effect of foreign aid to educational development in Nigeria?

Table 2 shows an average mean score of 2.61 for foreign donors in Nigeria. This implies that foreign aid on education has positive impact on the educational development. It also indicates that success rates have recorded in the areas of infrastructure in the educational institutions, ICT, Universal Basic Education, SDGs as well as improvement in science and technology, teacher education and student academic achievement. 
Table 2: Foreign stakeholders/donors perceptions on effect of foreign aid on educational development in Nigeria.

\begin{tabular}{|c|c|c|c|c|c|c|}
\hline \multirow{2}{*}{$\mathrm{S} / \mathrm{N}$} & \multirow{2}{*}{ ITEM } & \multicolumn{5}{|c|}{ RESPONSES } \\
\hline & & SA & $\mathrm{A}$ & $\mathrm{D}$ & SD & $x$ \\
\hline 1 & $\begin{array}{l}\text { Do you feel foreign aid has helped Nigeria to achieve SDGs } 4 \\
\text { (Ensure inclusive and equitable quality education and promote } \\
\text { lifelong learning opportunities for all)? }\end{array}$ & 5 & 12 & 26 & 7 & 2.30 \\
\hline 2 & $\begin{array}{l}\text { Do you feel foreign aid has improved essential infrastructure in } \\
\text { the educational institutions? }\end{array}$ & 16 & 20 & 10 & 4 & 2.96 \\
\hline 3 & $\begin{array}{l}\text { Has the foreign aid helped Nigeria to achieve Universal Basic } \\
\text { Education goals? }\end{array}$ & 13 & 16 & 12 & 9 & 2.66 \\
\hline 4 & $\begin{array}{l}\text { Do you feel Foreign aid has improved Information and } \\
\text { communication technology in Nigeria education institutions? }\end{array}$ & 12 & 14 & 19 & 5 & 2.66 \\
\hline 5 & $\begin{array}{l}\text { Do you feel the foreign aid has led to improvement in the outcome } \\
\text { of education at primary, Junior and secondary school levels? }\end{array}$ & 12 & 17 & 17 & 4 & 2.74 \\
\hline 6 & $\begin{array}{l}\text { Do feel foreign aid has negative effects on educational } \\
\text { development in Nigeria? }\end{array}$ & 12 & 13 & 20 & 5 & 2.64 \\
\hline 7 & $\begin{array}{l}\text { Do you feel foreign aid has improved science and technology } \\
\text { through research innovations in Nigeria universities? }\end{array}$ & 11 & 22 & 14 & 3 & 2.64 \\
\hline 8 & $\begin{array}{l}\text { Do you think foreign aid has led to improvement of student } \\
\text { outcome at senior secondary school level }\end{array}$ & 11 & 12 & 19 & 8 & 2.52 \\
\hline 9 & $\begin{array}{l}\text { Do you feel foreign aid has improved school enrollment of girl } \\
\text { child education in Nigeria? }\end{array}$ & 2 & 22 & 12 & 14 & 2.24 \\
\hline 10 & $\begin{array}{l}\text { Do you feel Nigeria rely on foreign aid intervention in the area of } \\
\text { education? }\end{array}$ & 14 & 16 & 12 & 8 & 2.72 \\
\hline & Overall Mean & & & & & 2.61 \\
\hline
\end{tabular}

Table 3: Independent sample for mean scores of perceptions of national and foreign stakeholders with regard to effect of foreign aid to educational development in Nigeria

\begin{tabular}{|l|r|r|r|r|r|r|}
\hline Respondents & $\mathbf{N}$ & Mean & Df & t-cal & t-crit & Decision \\
\cline { 1 - 3 } National stakeholders & 50 & 2.66 & 18 & 0.42 & 1.73 & ACCEPTED \\
\cline { 1 - 3 } Foreign donors & 50 & 2.61 & & & & \\
\hline
\end{tabular}

The information in Table 3 reveals a calculated t (0.42) which is less than the critical t (1.73) at 0.05 level of significance. Table 1 shows that the calculated $t(0.42)$ is not significant at .05 level of significance thus, the null hypothesis is accepted. The results of independent samples t-test indicated therefore that there is no significant difference between the perceptions of national and foreign stakeholders on the effect of foreign aid on educational development in Nigeria

\section{Discussion}

The overall mean score of $\mathbf{2 . 6 6}$ for national stakeholders' perceptions support the view that foreign aid on education has affected Nigerian education sector positively. It shows clearly that stakeholders from Nigerian education sector and stakeholders from donor countries strongly agree that foreign aid has positive impact on the educational development in the area of UBE, SDGs, ICT, science and technology, human resources and student performances. 
However, it has been found in the study that foreign aid on education has made Nigeria to rely heavily on foreign donors. Consequently, the national budget on education was not satisfactorily for last five years.

It has also been observed that participants' responses on SDG Goal 4 with average mean scores of 2.72; this indicated that Nigeria has been able to achieve this goal with the help of foreign aids. In the same vein, in Nigeria, Universal Basic Education has become affordable and sustainable and Nigeria has achieved quality education for all as set in 1999.

The finding of the study also reveals that foreign aid to education has developed essential infrastructure required for the educational institutions across the country.

The results of the study indicate that there is notable effect of official development assistance on educational institutions in the area of research innovations, advancement in science and technology in Nigerian Universities through scholarships, etc.

In summary, this study found some evidences that foreign aid on education has immediate effects on educational policies and policy implementations in Nigeria and also discovered that there is no significant difference between the perceptions of national stakeholders and foreign donors on the negative impact of foreign aids on Nigeria educational development.

\section{Conclusions and Recommendations}

Based on the findings, the study concludes that; i) the foreign aid intervention programs have positive impact on the infrastructural development in Nigerian education sector; ii) The foreign education intervention programs have positive impacts on the performance of teachers in our schools; iii) The foreign aids to education has helped Nigeria to achieve SDG and UBE goals; iv) the foreign aids to education have encouraged Nigerian school enrollment at primary and secondary school levels; and v) the foreign aid to education has improved ICT and science and technology in higher institutions.

Conclusively, the foreign aid to education has a positive impact on Nigeria education development.

Based on the findings of the study, it is recommended that better approaches must be engaged in order to ensure effectiveness with a critical restructuring with respect to the processes surrounding foreign aid delivery. In the light of the aforesaid, the following recommendations will help improve on previous results of foreign aids:

i. Donor countries / agencies should allow recipient countries to design and formulate their own policies according to their culture and traditions;

ii. Nigeria should not too heavily rely on foreign aids because it makes the country more dependent on others, instead, should rely on its own resources; and

iii. There is need to give more attention for the institutional development. Nigerian foreign aid should be used for the capacity building of the institutions. Moreover, the aid should be labor-intensive instead of capital-intensive.

\section{Conflict of Interest}

There is no conflict of interest to be declared in this paper. 


\section{References}

Abdulhamid, Y. (2008). Nigeria Received N696 Billion Foreign Aid in 8 Years. Retrieved from http:// allafrica.com/stories/200809250385.html

Adewole, A. (2014). Governance reform and the challenge of implementing public procurement law regime across Nigerian state and local governments. International Journal of Public Administration and Management Research (IJPAMR), 2(4), 25-32.

Adeyeye, J. (2013). stolen aid slays development. Journal of art and social sciences. 7(203)2151-6200

Alabi, R.A. (2012). Sectoral analysis of impact of foreign aid in Nigeria, adynamic specification. Ambrose Alli University, Ekpoma, Nigeria. 7(1S1)52.

Alemu, A.M., Lee, S. (2015). Foreign aid on economic growth in Africa: a comparison of low and middle-income countries. South African Journal of Economic and Management Sciences. 18(4), 449-462

Amassoma, D. (2014). The linkage between foreign aid and economic growth in Nigeria. International Journal of Economic Practices and Theories. 4(6), 1007-1017.

Andrews, N. (2009). Foreign aid and development in Africa: What the literature says and what the reality is. Journal of African Studies and Development, 1(1), 8.

Dreher, A., \& Lohmann, S. (2015). Aid and growth at the regional level. Oxford Review of Economic Policy, 31(3-4), 420-446.

Durbarry, R., Gemmell, N., \& Greenaway, D. (1998). New evidence on the impact of foreign aid on economic growth $.98 / 8$.

Fasanya, O., Onakoya, O. (2012). Does foreign aid accelerate economic growth? an empirical analysis for Nigeria. International Journal of Economics and Financial Issues. 2, 423-431.

Galiani, S., Knack, S., Xu, L.C., \& Zou, B. (2014). The effect of aid on growth-Evidence from a quasi-experiment. The World Bank Policy Research. Retrieved from http://documents.worldbank.org/ curated/en/730581468159302660/pdf/WPS6865.pdf

Gani, A., \& Clemes, M. D. (2003). Aid type and its relationship with human well being. International Journal of Social Economics, 30(6), 666-678.

Gomanee, K., Girma, S., \& Morrissey, O. (2002, March). Aid and growth: Accounting for transmission mechanisms in sub-Saharan Africa. Presented paper at understanding poverty and growth in sub-Saharan Africa conference, University of Oxford.

Hayter, (1971). Aid as imperialism. Economic assistance. Penguin books, pp 222.

Oshewolo, S. (2011). Poverty Reduction and the Attainment of the MDGS in Nigeria: Problems and Prospects. Africana, 5(2), 211-238.

Ouattara, B. (2006). Foreign aid and government fiscal behavior in developing countries: Panel data evidence. Economic Modeling. 7(23), 506-514.

Rostow, W. W., \& Rostow, W. W. (1990). The stages of economic growth: A non-communist manifesto. Cambridge university press.

Tarp, F., \& Director, U. N. U. (2009). Aid effectiveness. A Note Prepared Based Both on Joint Work with Channing Arndt and Sam Jones Including an Unpublished Report for NORAD and 2009 UNU-WIDER Research Paper Entitled “Aid and Growth: Have We Come Full Circle?” Dated September 2009, 1-22. 